\title{
TEMPORAL PATTERNS OF LIPOPEROXIDATION AND ANTIOXIDANT ENZYMES ARE MODIFIED IN THE HIPPOCAMPUS OF VITAMIN A-DEFICIENT RATS
}

\author{
Lorena S. Navigatore Fonzo ${ }^{1,2}$, Rebeca S. Golini ${ }^{1}$, Silvia M. Delgado ${ }^{1}$, Ivana T. Ponce ${ }^{1}$, \\ Myrta R. Bonomi ${ }^{2}$, Irma G. Rezza ${ }^{1}$, María S. Gimenez², and Ana C. Anzulovich ${ }^{1,2,{ }^{*}}$ \\ ${ }^{1}$ Laboratory of Chronobiology, Multidisciplinary Institute of Biological Research, National Council \\ of Science and Technology, National University of San Luis. Chacabuco y Pedernera, \\ D5700HHW, San Luis, Argentina \\ ${ }^{2}$ Laboratory of Nutrition and Environment, Multidisciplinary Institute of Biological Research, \\ National Council of Science and Technology, National University of San Luis. Chacabuco y \\ Pedernera, D5700HHW, San Luis, Argentina
}

\section{Abstract}

Animals can adapt their behavior to predictable temporal fluctuations in the environment through both, memory-and-learning processes and an endogenous time-keeping mechanism. Hippocampus plays a key role in memory and learning and is especially susceptible to oxidative stress. In compensation, antioxidant enzymes activity, such as Catalase (CAT) and Glutathione peroxidase (GPx), has been detected in this brain region. Daily rhythms of antioxidant enzymes activitiy, as well as of glutathione and lipid peroxides levels, have been described in brain. Here, we investigate day/night variations in lipoperoxidation, CAT and GPx expression and activity, as well as the temporal fluctuations of two key components of the endogenous clock, BMAL1 and PER1, in the rat hippocampus and evaluate to which extent vitamin A deficiency may affect their amplitude or phase. Holtzman male rats from control, vitamin A-deficient and vitamin A-refed groups were sacrificed throughout a 24-h period. Daily levels of clock proteins, lipoperoxidation, CAT and GPx mRNA, protein, and activity, were determined in the rat hippocampus obtained every 4 or $5 \mathrm{~h}$. Gene expression of RAR $\alpha$ and RXR $\beta$ was also quantified in the hippocampus of the three groups of rats. Our results show significant daily variations of BMAL1 and PER1 protein expression. Rhythmic lipoperoxidation, CAT, and GPx, expression and activity, were also observed in the rat hippocampus. Vitamin A deficiency reduced RXR $\beta$ mRNA level, as well as the amplitude of BMAL1 and PER1 daily oscillation, phase-shifted the daily peak of lipoperoxidation, and had a differential effect on the oscillating CAT and GPx mRNA, protein, and activity. Learning how vitamin A deficiency affects the circadian gene expression in the hippocampus may have an impact on the neurobiology, nutritional and chronobiology fields, emphasizing for the first time the importance of nutritional factors, such as dietary micronutrients, in the regulation of circadian parameters in this brain memory-and-learning-related region.

\section{Keywords}

circadian rhythm; catalase; glutathione peroxidase; retinoid; brain

\footnotetext{
*To whom all correspondence should be addressed: Ana Anzulovich, Laboratory of Chronobiology (IMIBIO-SL, CONICET, UNSL). Edificio El Barco, 2do. Piso, Chacabuco y Pedernera, CP D5700HHW, San Luis, Argentina. Phone number: 54-2652-423789/424689 ext.160.acanzu@unsl.edu.ar.
} 


\section{INTRODUCTION}

Animals can adapt their behavior to predictable temporal fluctuations in the environment such as day/night period, temperature, food and water availability, risk of predation, through both, memory-and-learning processes and an endogenous time-keeping mechanism (Pravosudov and Clayton, 2002; Panda et al., 2003; Wiskott et al., 2006; Maiti et al., 2008). Time-of-day effects on learning and memory have been observed in human and rats (Winocur and Hasher, 2004). Hippocampus plays a key role in memory and learning and is especially susceptible to oxidative stress (Onodera et al., 2003; Cheng et al., 2004). In compensation, there is wide evidence of antioxidant enzymes, Catalase (CAT), Glutathione peroxidase 1 (GPx1) and Superoxide dismutase (SOD), activity in this brain region (Baydas et al., 2002; Manikandan et al., 2005). Interestingly, daily rhythms of SOD, GPx, and Glutathione reductase (GR) activities, as well as of glutathione (GSH) and malondialdehyde (MDA) levels, have been demonstrated in brain (Pablos et al., 1998; Baydas et al., 2002).

Lipid peroxides, a damaging product of reactive oxygen species (ROS) reaction on cellular lipids, are particularly elevated in brain (Noda et al., 1983; Triggs and Willmore, 1984). It has been reported that oxidative damage and increase in lipoperoxidation may induce a decline of cognitive function in cerebral cortex and hippocampus (Onodera et al., 2003) and that some prooxidant agents such as propionic acid, aluminum, ozone and aging, provoke oxidative stress and modify the antioxidant defense system causing an imbalance in the cellular redox state and impairment of learning and memory in hippocampus (Pettenuzzo et al., 2002; Gómez et al., 2005; Barhwal et al., 2007).

In the seventies, it was demonstrated that memory performances for associative learning oscillate in a circadian fashion across time, with high memory retention at multiples of 24 hours post-learning (Holloway and Wansley, 1973). This fluctuation was absent in suprachiasmatic nucleus (SCN)-lesioned rats, implicating the underlying role of the endogenous biological clock (Stephan and Kovacevic, 1978).

Even though the mammalian central clock is located in the SCN, most of the tissues and cells, if not all of them, have the molecular components of the circadian clock. The molecular clock machinery works through two interacting transcription/translation-based feedback loops, a positive and a negative one. The positive loop is constituted by the heterodimeric basic helix-loop-helix-Per Arnt Sim (bHLH-PAS) transcription factor: BMAL1:CLOCK (from Brain and Muscle $\underline{A}$ RNT Like protein 1: Circadian Locomoter Output Cycles Kaput protein) which binds to Ebox enhancers (CANNTG) to activate the transcription of other clock and clock-controlled genes (Reppert and Weaver, 2002). Thus, in mammalian cells, the BMAL1:CLOCK heterodimer drives the rhythmic transcription of three clock Period genes (Per1, Per2, and Per3), two clock Cryptochrome genes (Cry1 and Cry2) as well as other clock and clock-controlled genes (Panda and Hogenesch, 2004). As Per and Cry mRNAs are translated and proteins accumulate in the cytoplasm, they form PER-CRY complexes which, once phosphorylated, translocate into the nucleus, interact with BMAL1:CLOCK and inhibit BMAL1:CLOCK-mediated transcription of clock and clockcontrolled genes, a general mechanism conserved in many organisms (Reppert and Weaver, 2002; Panda and Hogenesch, 2004; Lee et al., 2004). Additionally, Rutter et al. (2001) have shown that a high $\mathrm{NAD}(\mathrm{P}) \mathrm{H} / \mathrm{NAD}(\mathrm{P})^{+}$ratio, which can be the product of a well balanced cellular redox state, favors BMAL1:CLOCK heterodimerization as well as its DNA binding in an in vitro system.

Vitamin A is a micronutrient involved in a wide spectrum of biological functions. More recently, a role for a vitamin A oxidized derivative, the retinoic acid (RA), has been 
established in phenomena related to higher cognitive function in the adult mouse brain (Etchamendy et al., 2003, Husson et al., 2004).

Besides their role as antioxidants and radical scavengers (Palacios et al., 1996; Anzulovich et al., 2000), Vitamin A and its derivatives, the retinoids, regulate most of the developmental, physiological and cellular processes by activating retinoid nuclear receptors. Thus, retinoids act through RA receptors (RARs, $\alpha, \beta$ and $\gamma$ ) and Retinoid X receptors (RXRs, $\alpha, \beta$, and $\gamma$ ), and while RARs bind both all-trans-RA (ATRA) and 9cis-RA, RXRs only bind 9cis-RA (Heyman et al., 1992). It is now known that, in the case of RARs and RXRs, transcription regulation is mediated either by RAR:RXR heterodimers or by RXR:RXR homodimers, which bind to RAREs and RXREs, respectively, on their target gene promoters (Soprano et al., 2004). Noteworthily, ATRA has been detected at relatively high levels in the central nervous system of adult rats, and the hippocampus/cortex area contains the highest proportion of RA in the brain (Werner and Deluca, 2002). Additionally, high expression of the retinoid receptors, RAR $\alpha, \operatorname{RAR} \gamma$ and RXR $\beta$, has been observed in the adult mouse hippocampus (Krezel et al., 1999, Zetterstrom et al. 1999) and it has been demonstrated that vitamin A deficiency deteriorates LTP, leading to learning and memory impairment, by reducing the expression of RAR $\beta$ and $\operatorname{RXR} \beta$ in the mouse and rat hippocampus (Etchamendy et al., 2003, Mao et al., 2006).

Day-night cycles are known as the main zeitgeber for a wide number of living beings, but it has been shown that also feeding cycles can entrain peripheral clocks, independent of light entrainment (Brewer et al., 2005). While the mechanism could remain unknown, examples of hormonal phase-shifting of circadian gene expression in peripheral organs begun to emerge with Balsalobre et al. (2000). Indeed, there is some evidence that in a liganddependent manner retinoid receptors can interact with the cellular clock machinery partners, CLOCK, or its homolog MOP4, and inhibit BMAL1:CLOCK and/or BMAL1:MOP4 heterodimer-mediated expression of circadian responsive genes (McNamara et al., 2002).

Above observations raise the possibility that nutritional factors might have an effect on the clock activity and circadian expression of target genes, for example, by modulating cellular redox state and/or BMAL1:CLOCK DNA-binding activity. Considering, vitamin A deficiency: a) produces oxidative stress, increasing lipid peroxidation levels and affecting antioxidant enzymes activities (Anzulovich et al., 2000), b) reduces the availability of retinoid nuclear receptors (Husson et al., 2003 and 2004) thus affecting the activity of cellular clock machinery partners such as CLOCK and BMAL1 (McNamara et al., 2002), and c) produces learning and memory impairments (Etchamendy et al., 2003, Mao et al., 2006), our objective was to evaluate the effect of vitamin A deficiency on the daily variation of clock gene expression, lipoperoxidation, and antioxidant defense systems, in the rat hippocampus, a peripheral oscillator with a crucial role in cognitive function.

Here, we show daily rhythmic expression of BMAL1 and PER1 clock components, and describe, for the first time at our knowledge, daily fluctuations in CAT and GPx expression as well as in their enzymatic activities in the rat hippocampus. Vitamin A nutritional deprivation not only modified BMAL1 and PER1 circadian expression, but also altered the day-night cycles of lipoperoxidation and antioxidant enzymes expression and activities, in this brain memory-and-learning-related region.

\section{MATERIALS AND METHODS}

\section{Animal Model and Diet}

Male Holtzman rats were bred in our animal facilities (National University of San Luis, Argentina), and maintained in a $21-23^{\circ} \mathrm{C}$ controlled environment with a $12 \mathrm{~h}$-light:12h-dark 
cycle. They were weaned at 21 days of age and immediately assigned randomly to either the experimental diet, devoided of vitamin A (vitamin A-deficient group) or the same diet with $4000 \mathrm{IU}$ of vitamin A (8 mg retinol as retinyl palmitate) per $\mathrm{Kg}$ of diet (control group). Feeding the animals with a vitamin A-free diet during three months, guarantees subclinical plasma retinol concentration and depleted retinol stores in liver (Anzulovich et al., 2000; Oliveros et al, 2000). At the end of the third month of treatment, half of the vitamin Adeficient rats were subsequently fed on the complete diet during 15 days to induce repletion of vitamin A (vitamin A-refed group). This group was used to study the reversibility of the possible changes caused by the vitamin deficiency. Rats were given free access to food and water throughout the entire experimental period. All experiments were conducted in accordance with the National Institutes of Health Guide for the Care and Use of Laboratory Animals (NIH Publications No. 80-23) and the National University of San Luis Committee's Guidelines for the Care and Use of Experimental Animals. Diets were prepared according to the AIN-93 for laboratory rodents (Reeves et al, 1993). Both, vitamin A-deficient and control diets had the following composition $(\mathrm{g} / \mathrm{kg})$ : 397.5 cornstarch, 100 sucrose, 132 dextrinized cornstarch, 200 lactalbumin, 70 soybean oil, 50 cellulose fiber, 35 AIN-93 mineral mix, 10 AIN-93 vitamin mix (devoided of vitamin A for the vitamin A-deficient diet), 3 L-cystine, 2.5 choline bitartrate, and 0,014 tert-butylhydroquinone. After the treatment period, six rats from each group were sacrificed at different time points throughout a 24-h period. Those time points are referred to as zeigeber times (ZT) with ZT=0 when animal room light is on. Hippocampi were removed on an ice-chilled plate, weighed and immediately placed in liquid nitrogen. All the experiments were repeated at least twice.

\section{Tissue homogenates and antioxidant enzymes activity}

Two pools of three left hippocampi each, extracted from control, vitamin A-deficient and vitamin A-refed rats at every time point (ZT2, ZT7, ZT12, ZT17 and ZT22), were homogenized in $1 / 5(\mathrm{w} / \mathrm{v})$ dilution in $120 \mathrm{mM} \mathrm{KCl}$ and $30 \mathrm{mM}$ phosphate buffer, $\mathrm{pH} 7.2$ at $4^{\circ} \mathrm{C}$. Suspensions were centrifuged at $800 \times \mathrm{g}$ for $10 \mathrm{~min}$ at $4^{\circ} \mathrm{C}$ to remove nuclei and cell debris. The pellets were discarded and supernatants were used to determine antioxidant enzyme activities. CAT, GPx, and SOD activities were determined by the methods of Aebi (1984), Flohe and Gunzler (1984), and McCord and Fridovich (1969), respectively. Briefly, CAT activity was determined by measuring the decrease in the absorption at $240 \mathrm{~nm}$ when $100 \mu \mathrm{l}$ of $3 \mathrm{mM} \mathrm{H}_{2} \mathrm{O}_{2}$ were added to a reaction medium containing $50 \mathrm{mM}$ phosphate buffer pH 7.3 and 1/500 dilution of enzymatic preparation. The pseudo-first-order reaction constant $\mathrm{k}^{\prime}\left(\mathrm{k}^{\prime}=\mathrm{k}[\mathrm{CAT}]\right)$ of the decrease in the $\mathrm{H}_{2} \mathrm{O}_{2}$ absorption was determined and catalase activity was calculated using $\mathrm{k}=4.6 \times 10^{7} \mathrm{M}^{-1} \mathrm{~s}^{-1}$ (Chance et al, 1979) and expressed in IU/mg prot. One CAT unit is defined as the amount of enzyme required to decompose $1 \mu \mathrm{M}$ of $\mathrm{H}_{2} \mathrm{O}_{2} / \mathrm{min}$. GPx activity was determined following NADPH oxidation at $340 \mathrm{~nm}$ in a reaction medium containing $0.2 \mathrm{mM} \mathrm{GSH}, 0.25 \mathrm{U} / \mathrm{ml}$ yeast glutathione reductase, $0.5 \mathrm{mM}$ tert-butyl hydroperoxide and 50mM phosphate buffer (pH 7.2). SOD activity was determined on the basis of its inhibitory effect on the rate of superoxide-dependent reduction of cytochrome $\mathrm{c}$ by xanthine-xanthine oxidase at $560 \mathrm{~nm}$. The reaction medium contained $50 \mathrm{mM}$ phosphate buffer (pH 7.8), $50 \mu \mathrm{M}$ xanthine, $20 \mu \mathrm{M}$ cytochrome $\mathrm{c}$ and xanthine oxidase to detect 0.025 absorbance units/min. One unit of SOD was defined as the amount of enzyme that inhibits cytochrome c reduction by $50 \%$. Protein was measured by the method of Lowry et al. (1951) using bovine serum albumin $(1 \mathrm{mg} / \mathrm{ml})$ as standard. All reagents were from Sigma-Aldrich Co.

\section{Lipoperoxidation levels}

Two pools of three left hippocampi each, extracted from control, vitamin A-deficient and vitamin A-refed rats at ZT2, ZT6, ZT10, ZT14, ZT18 and ZT22, were homogenized in 1/5 $(\mathrm{w} / \mathrm{v})$ dilution in $120 \mathrm{mM} \mathrm{KCl}$ and $30 \mathrm{mM}$ phosphate buffer, $\mathrm{pH} 7.2$ at $4^{\circ} \mathrm{C}$. Suspensions 
were centrifuged at $800 \mathrm{xg}$ for $10 \mathrm{~min}$ at $4^{\circ} \mathrm{C}$ to remove nuclei and cell debris. The pellets were discarded and supernatants were used to determine TBARs. Lipid peroxidation was quantified spectrophotometrically by determining MDA levels as thiobarbituric acid reactive substances (TBARS) according to Draper and Hadley (1990).

\section{mRNA isolation and RT-PCR}

Total RNA was extracted from three pools of two right hippocampi each. Hippocampus samples were isolated at ZT2, ZT6, ZT10, ZT14, ZT18 and ZT22 from control, vitamin Adeficient and vitamin A-refed rats. All RNA isolations were performed using the Trizol reagent (Invitrogen $\mathrm{Co}$ ) as directed by the manufacturers. Gel electrophoresis and ethidium bromide staining confirmed the integrity of the samples. Quantification of RNA was based on spectrophotometric analysis at $260 \mathrm{~nm} .3 \mu \mathrm{g}$ of total RNA were reverse-transcribed with 200 units of MMLV Reverse Transcriptase (Promega Inc.) using random hexamers in a 25 $\mu \mathrm{l}$ reaction mixture and following manufacturer's instructions. Transcript levels of CAT, SOD and GPx were determined by RT-PCR and normalized to beta-actin as endogenous control. Fragments coding for $\mu$-actin, CAT, SOD and GPx were amplified by PCR in $50 \mu \mathrm{l}$ of reaction solution containing $0.2 \mathrm{mM}$ dNTPs, $1.5 \mathrm{mM} \mathrm{MgCl} 2,1.25 \mathrm{U}$ of Taq polymerase, 50 pmol of each rat specific oligonucleotide primer and RT-generated cDNA (1/5 of RT reaction). The sequences of the specific primers are shown on Table 1. Samples were heated in a thermalcycler (My Cycler, BioRad) to $94^{\circ} \mathrm{C}$ for $2 \mathrm{~min}$, followed by 40 cycles of: (1) denaturation, $94^{\circ} \mathrm{C}$ for $1 \mathrm{~min}$; (2) annealing, $59^{\circ} \mathrm{C}$ during $1 \mathrm{~min}$; (3) extension, $72^{\circ} \mathrm{C}$ for 1 min. After 40 reaction cycles, the extension reaction was continued for another 5 minutes. PCR products were then electrophoresed on $2 \%(\mathrm{w} / \mathrm{v})$ agarose gel with $0.01 \%(\mathrm{w} / \mathrm{v})$ ethidium bromide. The amplified fragments were visualized under ultraviolet (UV) transillumination and photographed using a Cannon PowerShot A75 3.2MP digital camera. The mean of gray value for each band was measured using the NIH ImageJ software (Image Processing and Analysis in Java from http://rsb.info.nih.gov/ij/) and the relative abundance of each band was normalized according to the housekeeping $\beta$-actin gene, calculated as the ratio of the mean of gray value of each product to that of $\beta$-actin.

\section{Real Time PCR}

Relative quantification of RAR $\alpha$ and RXR $\beta$ mRNA levels was performed by Real-Time PCR using the ABI Prism ${ }^{\circledR} 7500$ thermocycler (Applied Biosystems, USA). Before the realtime PCR was performed, cDNA obtained by RT-PCR was diluted to $20 \mathrm{ng} / \mu \mathrm{l}$ with nucleasefree water. The diluted cDNA $(5 \mu \mathrm{l})$ was amplified in a $25 \mu \mathrm{l}$ final volume reaction mix containing 1X SYBR Green I fluorescent dye (Applied Biosystems, USA) and $500 \mathrm{nM}$ gene-specific primers (Table 1). Reactions were subjected to one step of $95^{\circ} \mathrm{C}$ for $5 \mathrm{~min}$ followed by 40 cycles of $95^{\circ} \mathrm{C}$ for $15 \mathrm{sec}$ and $60^{\circ} \mathrm{C}$ for $1 \mathrm{~min}$. Relative expression of the realtime PCR products was determined by the $\Delta \Delta \mathrm{Ct}$ method. This method calculates relative expression using the equation: fold induction $=2^{-[\Delta \Delta C t]}$, where $\mathrm{Ct}$ is the threshold cycle, ie, the cycle number at which the sample's relative fluorescence rises above the background fluorescence and $\Delta \Delta C t=[C t$ gene of interest (unknown sample) - Ct housekeeping gene (unknown sample)] - [Ct gene of interest (calibrator sample) - Ct housekeeping gene (calibrator sample)]. In this case, $\beta$-actin was chosen as housekeeping gene and one of the control samples as calibrator. Each sample was run in triplicate, and the mean $\mathrm{Ct}$ was used in the $\Delta \Delta \mathrm{Ct}$ equation. Data for the normalized transcript levels of RAR $\alpha$ and RXR $\beta$ are shown as means \pm S.E.M.

\section{Immunobloting}

Protein extracts were prepared from two pools of three left hippocampi each, obtained from each group of rats at ZT2, ZT6, ZT10, ZT14, ZT18 and ZT22, in buffer C (20 mM HEPES, $\mathrm{pH} 7.9,0.42 \mathrm{M} \mathrm{NaCl}, 1.5 \mathrm{mM} \mathrm{MgCl} 2,0.2 \mathrm{mM}$ EDTA, $0.5 \mathrm{mM}$ dithiothreitol, $0.5 \mathrm{mM}$ 
phenylmethylsulfonyl fluoride, $1 \mu \mathrm{g} / \mathrm{ml}$ leupeptin, $1 \mu \mathrm{g} / \mathrm{ml}$ of pepstatin, $1 \mathrm{mM}$ sodium fluoride, $5 \mathrm{sM}$ sodium orthovanadate, and $25 \%$ glycerol). Aliquots containing $40 \mu \mathrm{g}$ of total protein were subjected to electrophoresis in 4-12\% NuPageTM Bis-Tris gels (Invitrogen Life Technologies, Carlsbad, CA), and then transferred to Immobilon-PTM transfer membranes (Millipore, Bedford, MA). Immunoblot analyses were performed as described in the manufacturers' protocols for the detecting antibodies. Briefly, membranes were blocked in Blotto (5\% nonfat dry milk, $10 \mathrm{mM}$ Tris- $\mathrm{HCl}, \mathrm{pH} 8.0$, and $150 \mathrm{mM} \mathrm{NaCl}$ ) followed by $3 \mathrm{~h}$ incubation at RT with either goat anti-CAT, goat anti-GPx1, goat anti-BMAL1 or rabbit anti-PER1 antibodies (Santa Cruz Biotechnology, Santa Cruz, CA) in Blotto containing $0.05 \%$ thimerosal. After incubation with primary antibody, the membranes were washed in TBS (10 mM Tris- $\mathrm{HCl}, \mathrm{pH} 8.0$, and $150 \mathrm{mM} \mathrm{NaCl}$ ) containing $0.05 \%$ Tween-20, before incubation with horseradish-peroxide-conjugated donkey anti-goat, or goat anti-rabbit, $\operatorname{IgG}$ (Santa Cruz Biotechnology, Santa Cruz, CA) diluted 1:10,000 in Blotto for 1 hour at room temperature. After washing, antibody/protein complexes on membranes were detected using Vectastain DAB Peroxidase Substrate kit from Vector Laboratories (Burlingame, CA) and following the manufacturers indications. The mean of intensity of each band was measured using the NIH ImageJ software (Image Processing and Analysis in Java from http://rsb.info.nih.gov/ij/).

\section{Scanning of antioxidant genes upstream regions for putative E-box, RARE and RXRE sites}

To identify putative E-box, RAR (RARE), and/or RXR (RXRE) DNA consensus regulatory sites, CAT, GPx and SOD gene regulatory regions, up to 2000 bp upstream of the translation start codon, were scanned for significant matches using the MatInspector software (Quandt et al., 1995) from Genomatix (http://www.genomatix.de).

\section{Statistical Analysis}

Time point data were expressed as means \pm standard error of the mean (SE) and pertinent curves were drawn. Time series were computed by one-way ANOVA followed by Tukey's post-hoc test for specific comparisons. A $P$ value of less than 0.05 between time points was considered to be significant.

\section{RESULTS}

\section{Effect of vitamin A deficiency on antioxidant enzymes mRNA expression in the rat hippocampus}

First of all, to test whether vitamin A deficiency could have any effect on the antioxidant enzymes transcript levels in the rat hippocampus, CAT, GPx and SOD mRNA expression was analyzed by RT-PCR (Figure 1). We found vitamin A deficiency significantly decreased CAT and GPx mRNA levels in the hippocampus of rat $(\mathrm{P}<0.05$ and $\mathrm{P}<0.01$, respectively) and had no effect on SOD expression (data not shown), in comparison to controls. Moreover, 15 days of vitamin A refeeding restored transcript levels of CAT and GPx to control values.

\section{Daily patterns of lipoperoxidation and antioxidant enzymes in the rat hippocampus}

Once we confirmed vitamin A deficiency had an effect on CAT and GPx mRNA expression levels, we continued to test whether lipoperoxidation and antioxidant enzymes expression and activities followed a daily pattern in the hippocampus of rat. For that, samples were obtained throughout a 24h-period from control, vitamin A-sufficient, rats. Tissue extracts were prepared as described in the Materials and Methods section, and subjected to TBARS, RT-PCR, immunobloting and activity assays. The results revealed that lipoperoxidation (Figure 2, left panel) as well as mRNA expression, protein levels and activity of CAT 
(Figure 3A, B and C, left panels) and GPx (Figure 4A, B and C, left panels), follow a robust diurnal rhythm in the hippocampus of control rats.

We found MDA levels peak at ZT22 (P<0.01), the end of the activity (and catabolic) phase in rodents. This peak of lipoperoxidation overlaps with the highest level of CAT activity, at ZT22 (P<0.005; Figure 3C, left panel), and concurs with the GPx activity peak at the end-ofthe-night/beginning-of-the-day, ZT22-ZT2, phase ( $<<0.001$; Figure $4 \mathrm{C}$, left panel).

Diurnal rhythms were also observed in CAT and GPx mRNA expression and protein levels. Thus, the highest level of CAT mRNA expression is at ZT22 (P<0.001), preceding the maximal protein level observed at ZT10 ( $\mathrm{P}<0.005$; Figure $3 \mathrm{~A}$ and $\mathrm{B}$, left panels). In the case of GPx, transcript expression reaches its maximum at ZT2 $(\mathrm{P}<0.005)$ while protein level does it at ZT10 ( $<<0.001$; Figure 4A ad B, left panels).

\section{Temporal pattern of lipoperoxidation in the hippocampus of vitamin A-deficient rats}

Interestingly, we observed a 12-hour phase-shift in the daily pattern of lipoperoxidation in the hippocampus of vitamin A-deficient rats, with MDA levels peaking at ZT10 $(\mathrm{P}<0.0001$; Figure 2, central panel). Refeeding vitamin A-deficient rats with the control diet, shortened in 4 hours, but didn't completely reverted, the phase-shift observed in vitamin A-deficient animals in comparison to controls (Figure 2, right panel).

\section{Temporal expression and daily activity of CAT in the hippocampus of vitamin A deficient rats}

Daily rhythms of CAT gene and protein expression as well as enzymatic activity were essentially abolished, with no significant differences between values at different time points, in the hippocampus of vitamin A-deficient rats (Figure 3A, B and C, central panels). Fifteen days of vitamin A refeeding reverted the effects of vitamin A deficiency and recovered daily rhythmicity of mRNA $(\mathrm{P}<0.001)$, protein levels $(\mathrm{P}<0.0001)$ and enzymatic CAT activity $(\mathrm{P}<0.001)$, although we observed some phase shifts of maximums in comparison to controls (Figure 3A, B and C, right panels).

\section{Temporal expression and daily activity of GPx in the hippocampus of vitamin A deficient rats}

In this case, vitamin A deficiency phase-shifted the daily patterns of mRNA expression and enzymatic activity of GPx $(\mathrm{P}<0.01$ and $\mathrm{P}<0.001$, respectively; Figure $4 \mathrm{~A}$ and $\mathrm{C}$, central panels). Thus, GPx transcript level peak was phase shifted from ZT2 to ZT10 and GPx activity from ZT22 to ZT12. Fifteen days of vitamin A refeeding, start reversing the vitamin A deficiency effects on GPx expression and activity (Figure 4A and C, right panels).

\section{Putative RARE, RXRE and E-box sites on CAT and GPx genes upstream region}

Scanning of $2000 \mathrm{bp}$ upstream of the translation start codon of CAT, GPx and SOD in the Genomatix database (http://www.genomatix.de) revealed one RARE, two RXREs and five putative clock-responsive E-box elements on the CAT gene upstream region, while five RXREs and one E-box sites were found on the GPx gene upstream region (Figure 5). None of these responsive sites was present on SOD promoter (data not shown). Interestingly, we also found a retinoic acid-related orphan receptor a (RORa) responsive site (RORE) on the GPx promoter.

\section{RAR $\alpha$ and RXR $\beta$ expression levels in the hippocampus of vitamin A deficient rats}

Once we had knowledge about the presence of putative RARE, RXRE and E-box regulatory sites on the promoter of the CAT and GPx genes, continued to study the mRNA expression 
of retinoid nuclear receptors in the hippocampus of control, vitamin A-deficient and vitamin A-refed rats. Interestingly, vitamin A deficiency decreased the RXR $\beta$ transcript level $(\mathrm{P}<0.001)$, but had no effect on the RAR $\alpha$ mRNA expression. Refeeding vitamin Adeficient animals with control diet during 15 days, increased RARa mRNA level $(\mathrm{P}<0.05)$ but was not enough to restore the RXR $\beta$ mRNA expression to control level $(\mathrm{P}<0.001)$ (Figure 6).

\section{Daily rhythms of BMAL1 and PER1 expression in the hippocampus of vitamin A-deficient rats}

To test to which extent vitamin A deficiency could affect the circadian expression of key clock factors, we analyzed the protein levels of BMAL1 and PER1 during a 24-h period, in the hippocampus of control, vitamin A-deficient and vitamin A-refed rats. We observed BMAL1 and PER1 protein expression varies throughout a day in the rat hippocampus, with maximal protein levels at ZT22 and ZT2, respectively (Figure 7). Three months of vitamin A deficiency, reduced in $20 \%$ and $37 \%$ the amplitude of BMAL1 and PER1 oscillation, respectively (Figure 7). These effects were completely reverted after fifteen days of vitamin A refeeding.

\section{DISCUSSION}

\section{Vitamin A is indispensable for CAT and GPx transcript expression in the rat hippocampus}

Vitamin A is linked to a variety of factors determining the susceptibility to oxidative stress. Previous results from our lab indicate that three months of feeding the vitamin A-free diet causes a well established vitamin A deficiency, with a significant reduction of the vitamin levels in the rat liver and heart, associated to alterations in non enzymatic and enzymatic antioxidant defense system (Anzulovich et al.,2000; Oliveros et al., 2000). Aerobic organisms developed a complex and efficient network of antioxidant defenses to protect themselves against deleterious effects of reactive oxygen species and maintenance of tissue and cellular homeostasis. It has been demonstrated that vitamin A modulates the upregulation of several major scavenger enzyme genes, such as glutathione transferase (Xia et al., 1996). Similarly, in the current study, we found mRNA levels of CAT and GPx1 were significantly lower in the hippocampus of vitamin A-deficient rats, compared to controls (Figure 1). Since alterations in the antioxidant defense system in the hippocampus have been seen to cause imbalance in the cellular redox state and impairment of learning and memory (Pettenuzzo et al., 2002; Gómez et al., 2005), our observations made us wonder about the participation of vitamin A in the circadian regulation of the antioxidant/pro-oxidant balance in the hippocampus and its putative relevance in the daily cognitive function.

\section{Relevance of daily rhythms of lipoperoxidation, antioxidant enzymes and clock proteins in the hippocampus}

Lipid peroxidation is a unique mode of oxidative injury which is triggered and promoted by different radical and non-radical members of the ROS family, or by the catalytic decomposition of preformed lipid hydroperoxides by several agents in different tissues (Niki et al, 2005). Here, we observed lipoperoxidation follows a daily rhythm in the hippocampus of control rats with a peak time of TBARS at the end of the catabolic-, thereafter ROS producing, activity-phase in rats. Thus, such increase in the level of lipid peroxides at the end-of-the-night/beginning-of-the-day could be explained as a consequence of oxidative metabolism during the dark phase, as seen by Baydas et al. (2002) in rat cerebral tissue. These observations are also consistent with temporal patterns of lipoperoxidation observed by Subramanian et al. (2008) and Pandi-Perumal et al. (2008) in the brain. 
Diurnal rhythms of antioxidant GPx, SOD and GR activity have been observed in the rat brain, particularly, in the cerebral cortex (Baydas et al., 2002). Moreover, Pablos et al. (1998) found rhythms of GPx and GR in the hippocampus of chick. Here, we report, for the first time at our knowledge, daily variation of CAT and GPx activity as well as rhythmic CAT and GPx expression, at transcript and protein levels, in the rat hippocampus (Figures 3 and $4, \mathrm{~A}, \mathrm{~B}$, and $\mathrm{C}$, left panels).

It is well known that CAT eliminates $\mathrm{H}_{2} \mathrm{O}_{2}$, by reducing it to water and oxygen, and that GPx helps to prevent the formation of hydrogen and organic hydroperoxides, thus protecting the cell from damaging effects of those oxidizing species. As expected, temporal patterns of CAT and GPx activities observed in the rat hippocampus were consistent with the rhythm of lipoperoxidation. While the lowest CAT activity occurs during the light period and, at least in part, brings lipid peroxidation into the maximal level, highest CAT and GPx activities, practically concur with the nocturnal peak of lipoperoxidation. Thus, antioxidant enzymes would have a complementary and proper timing for protecting hippocampus against peroxides, maintaining lipoperoxidation at controlled fluctuating levels, with the lowest MDA concentration occurring during the diurnal, anabolic, period in rats (Figure 2, left panel). Studies made by Sani et al. (2006) and Baydas et al. (2002), have reported similar observations for rhythmic CAT and GPx activity, with maximal levels occurring during the dark phase in the mouse and rat brain. On the other hand, the location of enzymes activity peaks during the night-feeding-period, may suggest the influence of feeding cycle, and macro or micronutrients, such as proteins, carbohydrates, aspartate, glutamate or some vitamins, on those rhythms, as seen by Selmaoui and Thibault (2002), Manivasagam and Subramanian (2004) and Sivaperumal et al. (2007).

Interestingly, the nocturnal peaks of CAT and GPx antioxidant activity seen in the hippocampus of our control rats would be in phase with the best time for performing learning and memory tests seen by Winocur and Hasher (2004) in young rats.

On the other hand, daily variation in the expression and activity of the antioxidant systems, as well as the presence of E-box BMAL1:CLOCK responding sites found on the CAT and GPx promoters (Figure 5), suggest those antioxidant enzymes would be under the endogenous clock control. Indeed, we found maximal CAT and GPx mRNA expression follow BMAL1 protein peak at the end-of-the-night/beginning-of-the-day in the control rats (Figures 3A, 4A and 7, left panels) while the lowest levels of CAT and GPx expression occur after the negative regulator, PER1, protein peak (Figures 3A and 4A, left panels, and 7 , right panel). Recently, Hirayama et al. (2007) provided an attractive link between the regulation of the cellular reduction/oxidation (redox) state and the circadian control in the Z3 zebrafish embryonic cell line, which contains an independent, light-entrainable circadian oscillator. They showed that $\mathrm{H}_{2} \mathrm{O}_{2}$ acts as the second messenger coupling photoreception to the zebrafish circadian clock, and that CAT shows oscillating expression and activity patterns, antiphasic to Per1, Per2 and Cry1, expression. As shown in Figures 3 and 7 for control animals, our findings are in agreement with their observations. Additionally, Hirayama et al. (2007) observed that overexpression of CAT results in a reduced lightdependent Cry1a and Per2 gene induction while inhibition of CAT function enhances lightmediated inducibility of these clock genes. These and our findings would implicate the existence of a mutual negative regulation between antioxidant enzymes and clock gene and protein expression.

\section{Differential effects of Vitamin A deficiency on daily oscillating patterns in the rat hippocampus}

Interestingly, we observed vitamin A deficiency exerts differential effects on the circadian expression and activity of CAT and GPx. On one hand, daily oscillations of CAT transcript, 
protein and activity are shallower in the vitamin A-deficient rats in comparison to control and vitamin A-refed groups (Figure 3, central panels). On the other hand, Vitamin A deficiency did not abolish or attenuate rhythmicity, but clearly phase-shifted day-night fluctuations of GPx mRNA expression and activity. Thus, a significant 8-h phase-shift of the GPx mRNA maximum and a 14-h phase-shift of GPx activity were observed in the hippocampus of vitamin A-deficient rats (Figure 4A and C, central panels). In both cases, temporal changes in enzymatic activity follow changes in mRNA levels suggesting vitamin A-deficiency affects the circadian expression of CAT and GPx at the transcriptional level. Although others have tested and demonstrated the effects of nutritional factors, such as aspartate, glutamate or changes in feeding schedule (Selmaoui and Thibault, 2002; Manivasagam and Subramanian, 2004; Sivaperumal et al., 2007) on the circadian expression of antioxidant enzymes, this would be, at least at our knowledge, the first published report on the effects of vitamin A deficiency on the daily rhythmicity of CAT and GPx expression and activity and its putative impact on the circadian functionality of a brain region.

The presence of different putative retinoid- and clock-responsive elements on the CAT and GPx gene upstream regions shown in Figure 5, would explain, at least in part, a differential regulation of these genes at transcriptional level as well as the distinct response to the vitamin A deficiency seen in this study. Thus, CAT promoter seems more responsive and sensitive to clock control through its five E-boxes. Shallower daily CAT expression and activity could be either a consequence of the loss of BMAL1 and PER1 rhythmicity or, taking into account Hirayama et al. (2007) findings, either the cause of the loss of clock proteins oscillation.

In the case of GPx upstream region, besides a larger number of RXR sites, it has only one Ebox and one RORE sites. RORa in the SCN or other brain regions is a retinoid-related orphan receptor recently incorporated to the molecular clock machinery (Sato et al., 2004), which activates BMAL1 transcription in a 24-h cycle. It has been shown that RORamediated transcription is activated synergistically by RAR in Pukinje cerebellar cells (Matsui, 1997), evidencing a functional interaction between RORa and RAR transcription factors. RARs operate as heterodimers with RXRs (Soprano et al., 2004). In these studies, vitamin A deficiency had no effect on the RAR $\alpha$ mRNA expression but significantly reduced the RXR $\beta$ transcript level (Figure 6). Taking into account the presence of RXR responsive sites on CAT and GPx genes upstream region (Figure 5), the lower availability of RXR $\beta$ might affect some necessary transcriptional interactions to maintain rhythmic expression of antioxidant enzymes genes; for example, affecting either RXR heterodimerization, either RORa-mediated transcriptional activation of clock (BMAL1) or clock-controlled (GPx) cycling genes. These last questions led us to test whether vitamin A deprivation modifies the circadian expression of key endogenous clock proteins such as BMAL1 and PER1, a positive and a negative clock transcription factor, respectively.

Interestingly, we observed vitamin A deficiency was able to reduce in a 20 and 37\% the BMAL1 and PER1 rhythms amplitude. Even thought there are many reports that associate vitamin deficiencies with altered daily expression patterns, just a very few report the effect of nutritional deficiencies on circadian clock gene expression, and only one determines the effect of vitamin A deficiency on the oscillating Bmal1 and Per2 gene expression (Shiari et al., 2006). Conversely to what we observed in the hippocampus of vitamin A deficient rats, Shirai et al. (2006) found that circadian expression of clock genes is maintained in the liver of Vitamin A-deficient mice. This lead us to suggest a tissue-specific role for vitamin A given by a tissue-specific distribution of its nuclear receptors, that is RXR $\alpha, R A R \alpha$ and RAR $\beta$ being the most abundant in the liver (Ulven et al., 1998) and RXR $\beta, \operatorname{RAR} \alpha$, and RAR $\gamma$, being the ones in the hippocampus (Krezel et al., 1999, Zetterstrom et al. 1999). 
Thus, vitamin A deficiency might affect transcriptional and/or post-transcriptional processes, either by affecting RARs- or RXRs-mediated transcriptional regulation of CAT and GPx, either by affecting the formation of BMAL1:CLOCK heterodimer or its interaction with the antioxidant enzymes promoters.

\section{Recovering of daily clock proteins and antioxidant enzymes expression rhythms in the hippocampus of vitamin A-refed rats}

Even thought refeeding vitamin A-deficient animals with the control diet during 15 days was not enough to restore the mRNA expression of RXR $\beta$ to control level (Figure 6), it was sufficient for recovering daily rhythmicity of BMAL1 and PER1 protein levels (Figure 7). These observations would allow us to explain the, in some cases complete in other partial, recovering of vitamin A-refed rats. Interestingly, CAT circadian rhythms were almost completely recovered after refeeding with the vitamin A-sufficient (control) diet. In this case, a higher number of Ebox sites on the CAT gene $5^{\prime}$ regulatory region is in agreement with the recovering of BMAL1 and PER1 circadian patterns (Figure 7). On the other hand, studies of RAR null and RXR mutations, have shown a compensatory activity of other RARs or RXRs when one RAR is not produced (Krezel et al., 1996) or one RXR is mutated and not functional (Vivat-Hannah et al., 2003). In our case, vitamin A refeeding increased RAR $\alpha$ mRNA level and, as shown in Figure 5, CAT gene has, besides two RXREs, a RARE site on its promoter. All above observations could explain daily CAT recovering from vitamin A deficiency when animals were refed with the control diet. However, lipoperoxidation and GPx circadian patterns were half-a-way restored in the vitamin A-refed group, as expected since GPx gene promoter is richer in RXRE but lacks of RARE sites and thereafter, it is probably more sensitive to the significant lowered and unrecovered RXRs levels.

\section{Conclusion}

Throughout a whole 24-h cycle, our study shows that CAT and GPx expression and activity present a daily rhythmicity in the rat hippocampus. This might reveal an interesting strategy to respond to the challenge of daily oxidative stress in this brain region. Temporal patterns of lipoperoxidation, CAT and GPx expression and activity, as well as daily oscillation of clock BMAL1 and PER1 proteins, showed dramatic changes under the nutritional vitamin A deficiency. Thus, the daily variation of physiological parameters and functions might be under the control of both endogenous and external factors such as environmental or nutritional ones. The presence of an endogenous biological clock is fundamental for life at all levels of an organism and as we and others have shown hippocampus does not run away from this.

Taken together, the results presented here would contribute to define, for the first time, a possible role for vitamin A as a rhythm regulator in the establishment of circadian clock and antioxidant enzyme systems. On the other hand, learning how vitamin A deficiency affects the circadian expression of genes involved in the antioxidant defense system in the hippocampus may have an impact on the neurobiology, nutritional, and chronobiology fields, emphasizing for the first time the importance of nutritional factors such as dietary micronutrients in the regulation of circadian parameters in the brain memory-and-learningrelated regions. We would also expect that emerging data from this and future studies would highlight retinoid signalling pathways as potential novel therapeutic targets for cognitive as well as for clock-related deficits. 


\section{Acknowledgments}

Grant sponsor: Fogarty International Center, National Institutes of Health (USA). Grant number: GRIP R01TW006974.

This work was mainly supported by NIH Res. Grant R01-TW006974 funded by the Fogarty International Center (USA) and by the National University of San Luis, Grant P-8104. We thank Dr. Ana Rastrilla and LABIR (UNSL) for providing us with Holtzman rats. We acknowledge Mr Mario Quiroga for his assistance in making diets and taking care of animals. The dextrinized cornstarch was generously provided by Productos de Maíz SRL (Bragado, BA, Argentina).

\section{Abbreviations}

$\begin{array}{ll}\text { ANOVA } & \text { analysis of variance } \\ \text { ATRA } & \text { all-trans-retinoic acid } \\ \text { 9cisRA } & \text { 9-cis-retinoic acid } \\ \text { CAT } & \text { catalase } \\ \text { GPX } & \text { glutathione peroxidase } \\ \text { GSH } & \text { glutathione } \\ \text { MDA } & \text { malondialdehyde } \\ \text { RAR } & \text { retinoic acid receptor } \\ \text { RARE } & \text { retinoic acid responsive element, ROS, reactive oxygen species } \\ \text { RORE } & \text { retinoid-related orphan receptor responsive element } \\ \text { RXR } & \text { retinoid X receptor } \\ \text { RXRE } & \text { retinoid X responsive element } \\ \text { SCN } & \text { suprachiasmatic nucleus } \\ \text { SOD } & \text { superoxide dismutase } \\ \text { TBARS } & \text { thiobarbituric acid reactive substances } \\ \text { ZT } & \text { zeitgeber time }\end{array}$

\section{References}

1. Aebi H. Catalase in vitro. Methods Enzymol. 1984; 105:121-126. [PubMed: 6727660]

2. Anzulovich AC, Oliveros LB, Muñoz E, Martinez LD, Gimenez MS. Nutritional vitamin A deficiency alters antioxidant defenses and modifies the liver histoarchitecture in rat. The J Trace Elem Exp Med. 2000; 13(4):343-357.

3. Balsalobre A, Brown SA, Marcacci L, Tronche F, Kellendonk C, Reichardt HM, Schutz G, Schibler U. Resetting of circadian time in peripheral tissues by glucocorticoid signaling. Science. 2000; 289:2344-2347. [PubMed: 11009419]

4. Barhwal K, Singh SB, Hota SK, Jayalakshmi K, Ilavazhagan G. Acetyl-L-carnitine ameliorates hypobaric hypoxic impairment and spatial memory deficits in rats. Eur J Pharmacol. 2007; 570(13):97-107. [PubMed: 17610872]

5. Baydas G, Gursu MF, Yilmaz S, Canpolat S, Yasar A, Cikim G, Canatan H. Daily rhythm of glutathione peroxidase activity, lipid peroxidation and glutathione levels in tissues of pinealectomized rats. Neurosci Lett. 2002; 323:195-198. [PubMed: 11959418]

6. Brewer M, Lange D, Baler R, Anzulovich A. SREBP-1 as a transcriptional integrator of circadian and nutritional cues in the liver. J Biol Rhythms. 2005; 20:195-205. [PubMed: 15851526] 
7. Chance B, Sies H, Boveris A. Hydroperoxyde metabolism in mammalian tissue. Physiol Rev. 1979; 59:527-605. [PubMed: 37532]

8. Cheng H, Fu YS, Guo JW. Ability of GDNF to diminish free radical production leads to protection against kainate-induced excitotoxicity in hippocampus. Hippocampus. 2004; 14(1):77-86. [PubMed: 15058485]

9. Draper, HH.; Hadley, M. Malondialdehyde determination as index of lipid peroxidation. In: Colowick, SP.; Kaplan, N0., editors. Methods of Enzymology. Vol. 186. Academic Press, Inc; 1990. p. 421-431.

10. Etchamendy N, Enderlin V, Marighetto A, Pallet V, Higueret P, Jaffard R. Vitamin A deficiency and relational memory deficit in adult mice: relationships with changes in brain retinoid signalling. Behav Brain Res. 2003; 145:37-49. [PubMed: 14529804]

11. Flohe, L.; Gunzler, WA. Assays of glutathione peroxidase. In: Colowick, SP.; Kaplan, N0., editors. Methods of Enzymology. Vol. 105. Academic Press Inc; 1984. p. 114-121.

12. Gómez M, Esparza JL, Nogués MR, Giralt M, Cabré M, Domingo JL. Pro-oxidant activity of aluminum in the rat hippocampus: gene expression of antioxidant enzymes after melatonin administration. Free Rad Biol \& Med. 2005; 38:104-111. [PubMed: 15589378]

13. Heyman RA, Mangelsdorf DJ, Dyck JA, Stein RB, Eichele G, Evans RM, Thaller C. 9-cis retinoic acid is a high affinity ligand for the retinoid X receptor. Cell. 1992; 68:397-406. [PubMed: 1310260]

14. Hirayama J, Cho S, Sassone-Corsi P. Circadian control by the reduction/oxidation pathway: catalase represses light-dependent clock gene expression in the zebrafish. Proc Natl Acad Sci U S A. 2007; 104(40):15747-52. [PubMed: 17898172]

15. Holloway FA, Wansley RA. Multiple retention deficits at periodic intervals after active and passive avoidance learning. Behav Biol. 1973; 9:1-14. [PubMed: 4738709]

16. Husson M, Enderlin V, Alfos S, Féart C, Higueret P, Pallet V. Triiodothyronine administration reverses vitamin A deficiency-related hypo-expression of retinoic acid and triiodothyronine nuclear receptors and of neurogranin in rat brain. Br J Nutr. 2003; 90(1):191-8. [PubMed: 12844391]

17. Husson M, Enderlin V, Alfos S, Boucheron C, Pallet V, Higueret P. Expression of neurogranin and neuromodulin is affected in the striatum of vitamin A-deprived rats. Mol Brain Res. 2004; 123:717. [PubMed: 15046861]

18. Krezel W, Dupé V, Mark M, Dierich A, Kastner P, Chambon P. RXR gamma null mice are apparently normal and compound RXR alpha +/-/RXR beta -/-/RXR gamma -/-mutant mice are viable. Proc Natl Acad Sci USA. 1996; 93(17):9010-9014. [PubMed: 8799145]

19. Krezel W, Kastner P, Chambon P. Differential expression of retinoid receptors in the adult mouse central nervous system. Neuroscience. 1999; 89:1291-1300. [PubMed: 10362315]

20. Lee C, Weaver DR, Reppert SM. Direct Association between Mouse PERIOD and CKI $\varepsilon$ Is Critical for a Functioning Circadian Clock. Molecular and Cellular Biology. 2004; 24(2):584-594. [PubMed: 14701732]

21. Lowry OH, Rosebrough NJ, Farr AL, Randall RJ. Protein measurement with Folin phenol reagent. J Biol Chem. 1951; 193:265-275. [PubMed: 14907713]

22. Maiti P, Muthuraju S, Ilavazhagan G, Singh SB. Hypobaric hypoxia induces dendritic plasticity in cortical and hippocampal pyramidal neurons in rat brain. Behav Brain Res. 2008; 189(2):233-43. [PubMed: 18321600]

23. Manikandan S, Srikumar R, Jeya Parthasarathy N, Sheela Devi R. Protective effect of Acorus calamus LINN on free radical scavengers and lipid peroxidation in discrete regions of brain against noise stress exposed rat. Biol Pharm Bull. 2005; 28(12):2327-2330. [PubMed: 16327175]

24. Manivasagam T, Subramanian P. Influence of monosodium glutamate on circadian rhythms of lipid peroxidation products and antioxidants in rats. Ital J Biochem. 2004; 53(1):23-27. [PubMed: 15356958]

25. Mao CT, Li TY, Qu P, Zhao Y, Wang R, Liu YX. Effects of early intervention on learning and memory in young rats of marginal vitamin A deficiency and it's mechanism. Zhonghua Er Ke Za Zhi. 2006; 44(1):15-20. 26. [PubMed: 16623998] 
26. Matsui T. Transcriptional regulation of a Purkinje cell-specific gene through a functional interaction between ROR alpha and RAR. Genes Cells. 1997; 2(4):263-272. [PubMed: 9224660]

27. Mc Cord JM, Fridovich I. Superoxide dismutase. An enzymatic tinction for erythrocuprein. J Biol Chem. 1969; 244:6019-6055.

28. McNamara P, Seo SP, Rudic RD, Sehgal A, Chakravarti D, FitzGerald GA. Regulation of CLOCK and MOP4 by nuclear hormone receptors in the vasculature: a humoral mechanism to reset a peripheral clock. Cell. 2001; 105:877-889. [PubMed: 11439184]

29. Niki E, Yoshida Y, Saito Y, Noguchi N. Lipid peroxidation: mechanisms, inhibition, and biological effects. Biochem Biophys Res Commun. 2005; 338:668-676. [PubMed: 16126168]

30. Noda Y, McGeer PL, McGeer EG. Lipid peroxide distribution in rat brain and the effect of hyperbaric oxygen. J Neurochem. 1983; 40:1329-1332. [PubMed: 6834064]

31. Onodera K, Omoi NO, Fukui K, Hayasaka T, Sizuki S, Abe K, Urano S. Oxidative damage of rat cerebral cortex and hippocampus, and changes in antioxidative defense systems caused by hyperoxia. Free Radic Res. 2003; 37(4):367-372. [PubMed: 12747730]

32. Oliveros L, Vega V, Anzulovich A, Ramirez D, Giménez MS. Vitamin A deficiency modifies antioxidant defenses and essential element contents in rat heart. Nutr Res. 2000; 20(8):1139-1150.

33. Pablos MI, Reiter RJ, Ortiz GG, Guerrero JM, Agapito MT, Chuang JI, Sewerynek E. Rhythms of glutathione peroxidase and glutathione reductase in brain of chick and their inhibition by light. Neurochem Int. 1998; 32(1):69-75. [PubMed: 9460704]

34. Palacios A, Piergiacomi VA, Catala A. Vitamin A supplementation inhibits chemiluminescence and lipid peroxidation in isolated rat liver microsomes and mitochondria. Mol Cell Biochem. 1996; 154:77-82. [PubMed: 8717420]

35. Panda S, Hogenesch JB. It's all in the timing: many clocks, many outputs. J Biol Rhythms. 2004; 19:374-387. [PubMed: 15534318]

36. Panda S, Hogenesch JB, Kay SA. Circadian light input in plants, flies and mammals. Novartis Found Symp. 2003; 253:73-82. discussion 82-8, 102-9, 281-4. [PubMed: 14712915]

37. Pandi-Perumal, SR.; Subramanian, P.; Trakht, I.; Cardinali, DP. Sleep disorders: diagnostics and therapeutics. Informa Healthcare; London, UK: 2008. Chapter 16: Chronopharmacology: Principle and applications in sleep medicine; p. 153-162.

38. Pravosudov VV, Clayton NS. A test of the adaptive specialization hypothesis: population differences in caching, memory, and the hippocampus in black-capped chickadees (Poecile atricapilla). Behav Neurosci. 2002; 116(4):515-22. [PubMed: 12148919]

39. Pettenuzzo LF, Schuck PF, Fontella F, Wannmacher CMD, Wyse AT, Dutra-Filho CS, Netto CA, Wajner M. Ascorbic acid prevents cognitive deficits caused by chronic administration of propionic acid to rats in the water maze. Pharm Biochem Behav. 2002; 73:623-629.

40. Quandt K, Frech KK, Karas H, Wingender E, Werner T. MatInd and MatInspector: new fast and versatile tools for detection of consensus matches in nucleotide sequence data. Nucleic Acids Res. 1995; 23:4878-4884. [PubMed: 8532532]

41. Reeves PG, Nielsen FH, Fahey GC Jr. AIN- purified diets for laboratory rodents: Final report of the American Institute of Nutrition ad hoc writing committee on the reformulation of the AIN-76A rodent diet. J Nutr. 1993; 123:1939-1951. [PubMed: 8229312]

42. Reppert SM, Weaver DR. Coordination of circadian timing in mammals. Nature. 2002; 418:935941. [PubMed: 12198538]

43. Rutter J, Reick M, Wu LC, McKnight SL. Regulation of Clock and NPAS2 DNA binding by the redox state of NAD cofactors. Science. 2001; 293:510-514. [PubMed: 11441146]

44. Sani M, Sebai H, Gadacha W, Boughattas NA, Reinberg A, Mossadok BA. Catalase activity and rhythmic patterns in mouse brain, kidney and liver. Comp Biochem Physiol Part B. 2006; 145:331-337.

45. Sato TK, Panda S, Miraglia LJ, Reyes TM, Rudic RD, McNamara P, Naik KA, FitzGerald GA, Kay SA, Hogenesch JB. A functional genomic strategy reveals Rora as a component of the mammalian circadian clock. Neuron. 2004; 43:527-537. [PubMed: 15312651]

46. Selmaoui B, Thibault L. The induction of low nocturnal secretion of melatonin caused by reverse feeding rhythms depends on availability of macronutrient diets. Nutr Neurosci. 2002; 5(6):417426. [PubMed: 12509071] 
47. Shirai H, Oishi K, Ishida N. Circadian expression of clock genes is maintained in the liver of Vitamin A-deficient mice. Neurosci Lett. 2006; 1;398(1-2):69-72.

48. Sivaperumal R, Subash S, Subramanian P. Influences of aspartate on circadian patterns of lipid peroxidation products and antioxidants in Wistar rats. Singapore Med J. 2007; 48(11):1033-1038. [PubMed: 17975694]

49. Soprano DR, Qin P, Soprano KJ. Retinoic acid receptors and cancers. Annu Rev Nutr. 2004; 24:201-221. [PubMed: 15189119]

50. Stephan FK, Kovacevic NS. Multiple retention deficit in passive avoidance in rats is eliminated by suprachiasmatic lesions. Behav Biol. 1978; 22:456-462. [PubMed: 567972]

51. Subramanian P, Dakshayani KB, Pandi-Perumal SR, Trakht I, Cardinali DP. 24-hour rhythms in oxidative stress during hepatocarcinogenesis in rats: effect of melatonin or alpha-ketoglutarate. Redox Rep. 2008; 13:78-86. [PubMed: 18339250]

52. Triggs WJ, Willmore J. In vivo lipid peroxidation in rat brain following intracortical $\mathrm{Fe}^{2+}$ injection. J Neurochem. 1984; 42:976-980. [PubMed: 6699647]

53. Ulven SM, Natarajan V, Holven KB, Løvdal T, Berg T, Blomhoff R. Expression of retinoic acid receptor and retinoid $\mathrm{X}$ receptor subtypes in rat liver cells: implications for retinoid signalling in parenchymal, endothelial, Kupffer and stellate cells. Eur J Cell Biol. 1998; 77(2):111-6. [PubMed: 9840460]

54. Vivat-Hannah V, Bourguet W, Gottardis M, Gronemeyer H. Separation of retinoid X receptor homo- and heterodimerization functions. Mol Cell Biol. 2003; 23(21):7678-7688. [PubMed: 14560013]

55. Werner EA, Deluca HF. Retinoic acid is detected at relatively high levels in the CNS of adult rats. Am J Physiol Endocrinol Metab. 2002; 282(3):E672-E678. [PubMed: 11832372]

56. Winocur G, Hasher L. Age and time-of-day effects on learning and memory in a non-matching-tosample test. Neurobiol Aging. 2004; 25:1107-1115. [PubMed: 15212835]

57. Wiskott L, Rasch MJ, Kempermann G. A functional hypothesis for adult hippocampal neurogenesis: avoidance of catastrophic interference in the dentate gyrus. Hippocampus. 2006; 16(3):329-43. [PubMed: 16435309]

58. Xia C, Hu J, Ketterer B, Taylor JB. The organization of the human GSTPI-1 gene promoter and its response to retinoic acid and cellular redox status. Biochem J. 1996; 13:155-161. [PubMed: 8546677]

59. Zetterstrom RH, Lindqvist E, Mata de Urquiza A, Tomac A, Eriksson U, Perlman T, Olson L. Role of retinoids in he CSN: differential expression of retinoid binding proteins and receptors and evidence for presence of retinoic acid. Eur J Neurosci. 1999; 11:407-416. [PubMed: 10051741] 


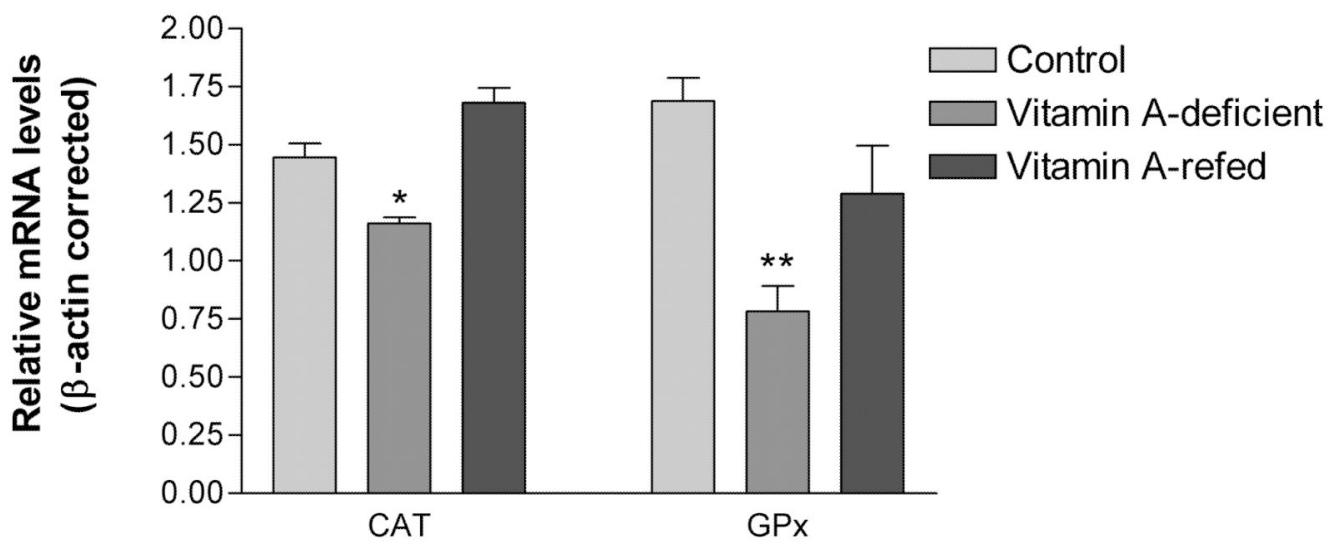

Figure 1. CAT and GPx mRNA levels in the hippocampus of control, vitamin A-deficient and vitamin A-refed rats

Bars represent mean \pm standard error of four animals per group performed in duplicates. Statistical analysis was performed using one-way ANOVA followed by Tukey test. $* \mathrm{P}<0,02 ; * * \mathrm{P}<0,05$. 

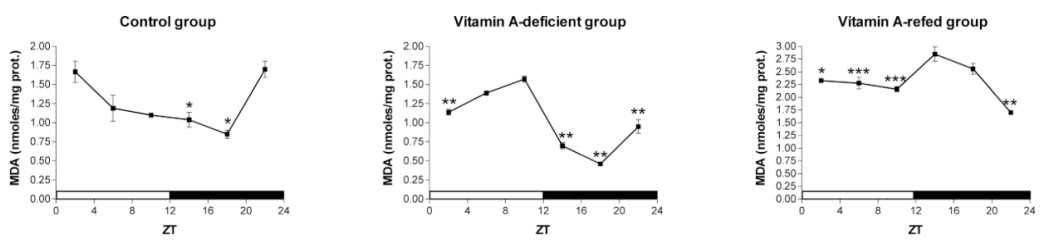

Figure 2. Day-night cycles of lipoperoxidation in the hippocampus of control, vitamin A-deficient and vitamin A-refed rats

MDA was measured by the thiobarbituric acid method. Each value represents the mean \pm SE of two pools of three left hippocampi each. Horizontal bars represent the distribution of light (open) and dark (closed) phases of the $24 \mathrm{~h}$ photoperiod. ZT is zeitgeber time, with ZT=0 when light is on. Statistical analysis was performed using one-way ANOVA followed by Tukey test with $* \mathrm{P}<0,05 ; * * \mathrm{P}<0,01$ and $* * * \mathrm{P}<0,001$ when compared indicated means with the corresponding maximal value in each group. 
A)
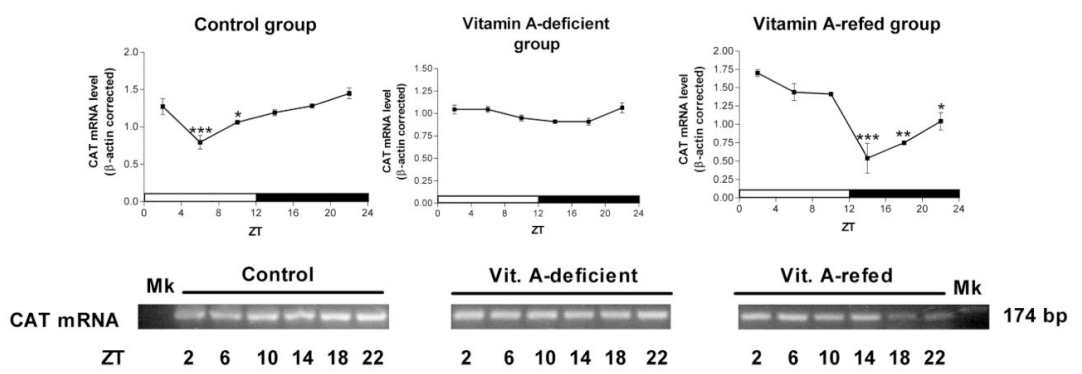

B)
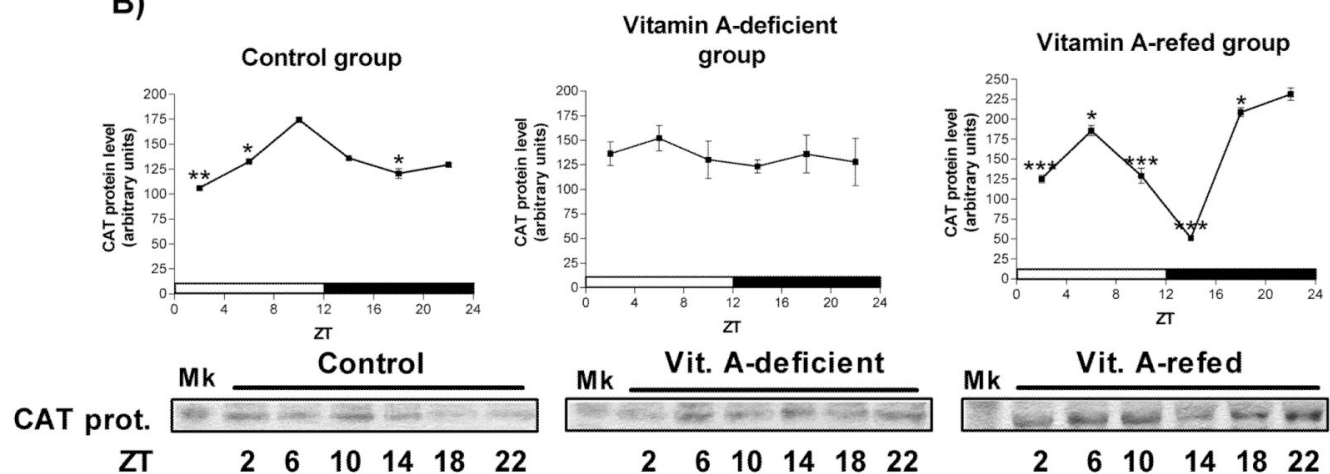

C)
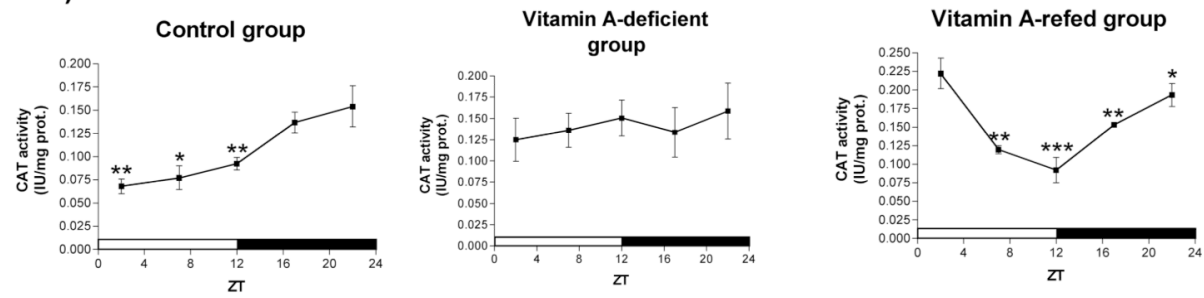

Figure 3. Daily rhythms of CAT mRNA expression (A), protein levels (B) and enzymatic activity (C), in the hippocampus of control, vitamin A-deficient and vitamin A-refed rats

Each value on the curve represents the mean \pm SE of three pools of two right hippocampi each (mRNA levels), or two pools of three left hippocampi each (protein levels and enzymatic activity), at a given ZT (with ZT=0 when light is on). Horizontal bars represent the distribution of light (open) and dark (closed) phases of the 24-h photoperiod. Statistical analysis was performed using one-way ANOVA followed by Tukey test with $* \mathrm{P}<0,05$; $* * \mathrm{P}<0,01$ and $* * * \mathrm{P}<0,001$ when indicated means were compared to the corresponding maximal value in each group. 
A)

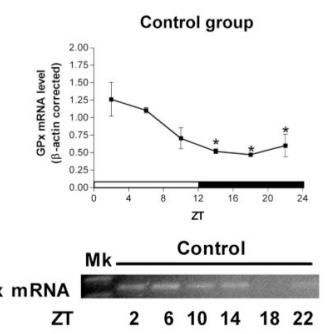

B)
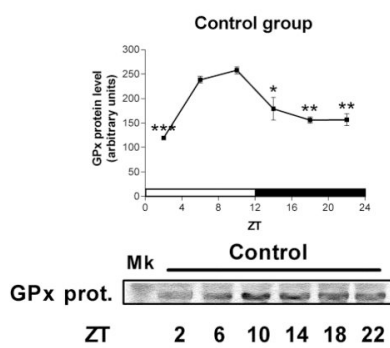

$\begin{array}{llllllll}\text { ZT } & & 2 & 6 & 10 & 14 & 18 & 22\end{array}$

C)

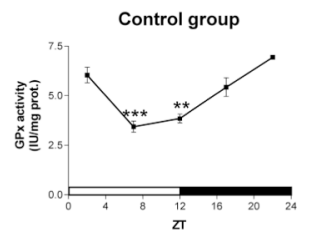

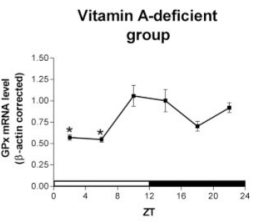

Vit. A-deficient

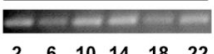

$\begin{array}{llllll}2 & 6 & 10 & 14 & 18 & 22\end{array}$
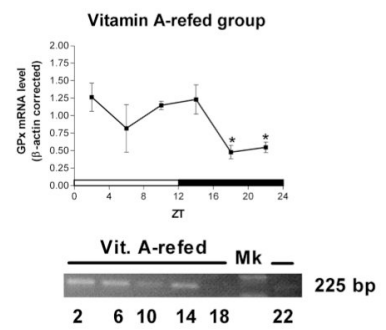

$\begin{array}{llllll}2 & 6 & 10 & 14 & 18 & 22\end{array}$
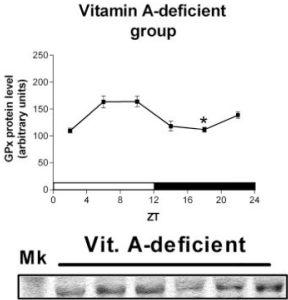

$\begin{array}{llllll}2 & 6 & 10 & 14 & 18 & 22\end{array}$

Vitamin A-deficient

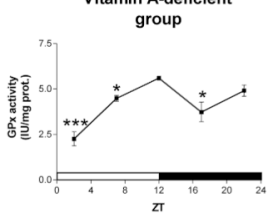

Vitamin A-refed group
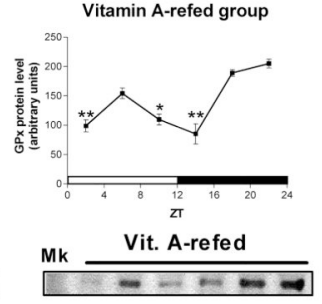

$\begin{array}{llllll}2 & 6 & 10 & 14 & 18 & 22\end{array}$

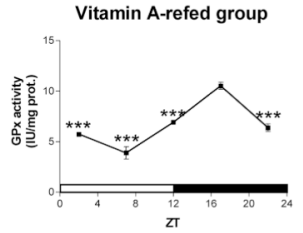

Figure 4. Daily rhythms of GPx mRNA expression (A), protein levels (B), and enzymatic activity (C), in the hippocampus of control, vitamin A-deficient and vitamin A-refed rats

Each value on the curve represents the mean \pm SE of three pools of two right hippocampi each (mRNA levels), or two pools of three left hippocampi each (protein levels and enzymatic activity), at a given ZT (with ZT=0 when light is on). Horizontal bars represent the distribution of light (open) and dark (closed) phases of the 24-h photoperiod. Statistical analysis was performed using one-way ANOVA followed by Tukey test with $* \mathrm{P}<0,05$; $* * \mathrm{P}<0,01$ and $* * * \mathrm{P}<0,001$ when indicated means were compared to the corresponding maximal value in each group. 


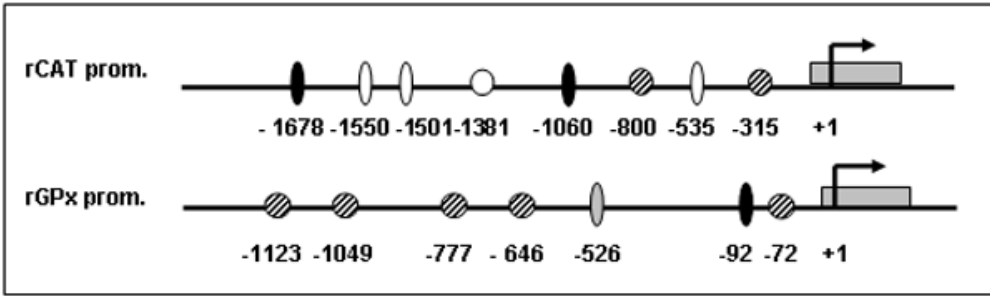

Figure 5. Schematic representation of RARE, RXRE and E-box sites on the 5' regulatory region of CAT and GPx genes

The accession \# for the sequences taken from the PubMed database are: CAT (Acc\#: AH004967) and GPx (Acc\#: AB004231). Arrows indicate the first translation codon, gray boxes represent exons, white circles are RAREsites, dashed circles RXREs, black ovals perfect E-box (CACGTG) sites and white ovals are E-box-like (CATATG, CATGTG or CACTTG) sites. Grey oval on rGPx promoter represents a RORE site. Negative (-) numbers indicate regulatory sites positions relative to the start of translation $(+1)$. 


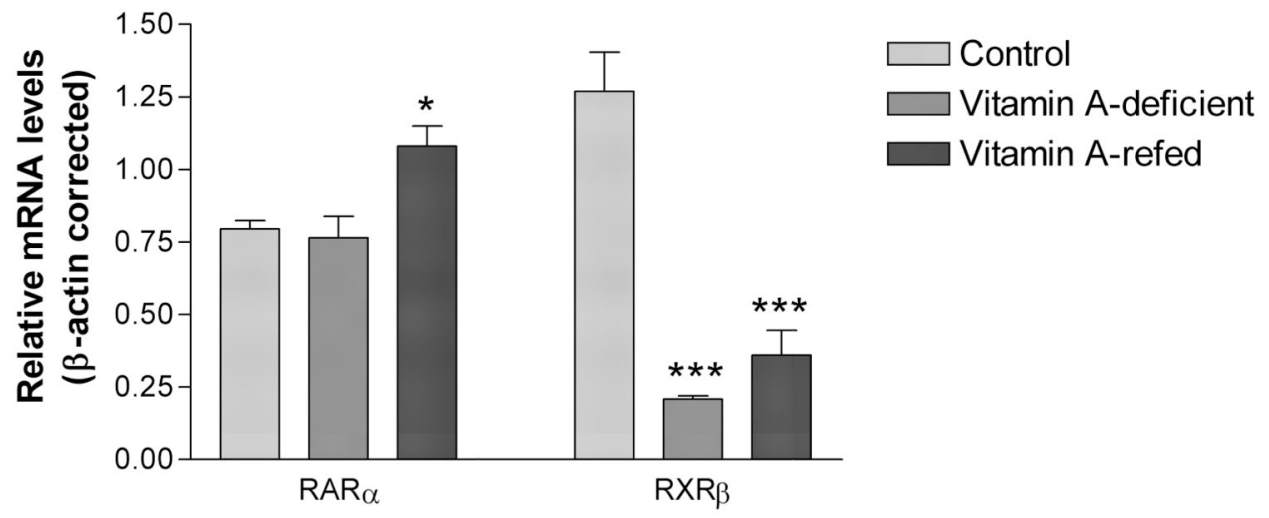

Figure 6. Transcript levels of RAR $\alpha$ and RXR $\beta$ in the hippocampus of control, vitamin Adeficient and vitamin A-refed rats

mRNA levels were determined by Real Time PCR and normalized to $\beta$-actin. Each bar represents the mean $\pm \mathrm{SE}$ of 4 samples in triplicates with $* \mathrm{P}<0,05$ and $* * * \mathrm{P}<0,001$ in comparison to control. 
A)
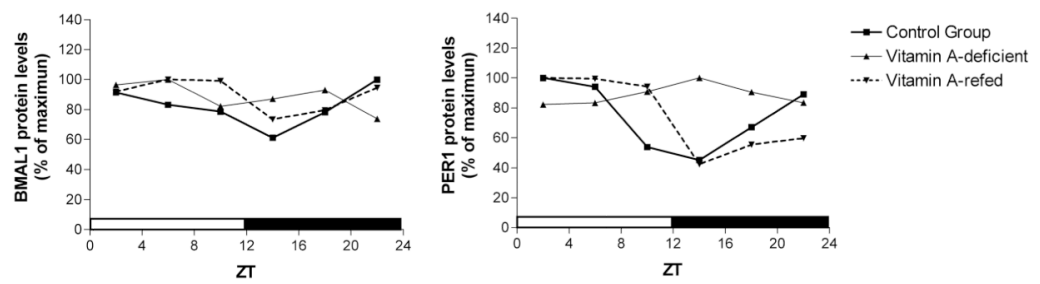

B)
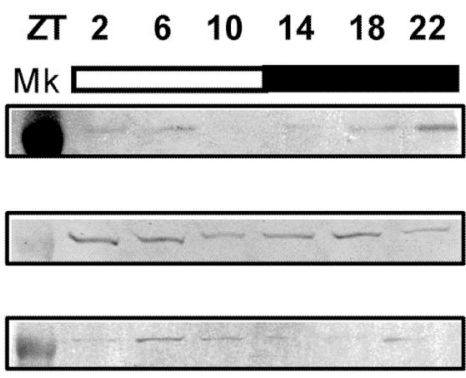

BMAL1
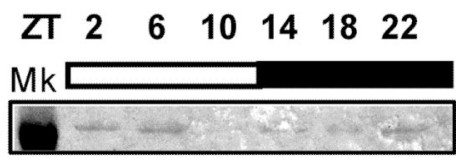

group

Vit. A-deficient group

Vit. A-refed group
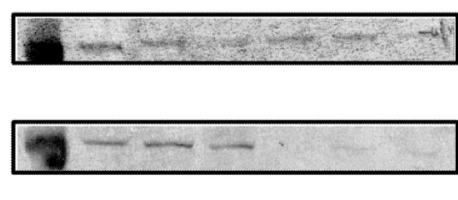

PER1

Figure 7. Daily rhythms of BMAL1 and PER2 protein levels in the hippocampus of control, vitamin A-deficient and vitamin A-refed rats

A) Densitometric quantitation of the Immunoblots representative data. Each value on the curve represents the percentage $(\%)$ of maximal protein expression at a given ZT, with ZT=0 when light is on. Horizontal bars represent the distribution of light (open) and dark (closed) phases of the 24-h photoperiod. B) Immunoblot analysis of protein extracted from control, vitamin A-deficient, and vitamin A-refed rat hippocampi obtained at ZT2, ZT6, ZT10, ZT14, ZT18 and ZT22. 
Table 1

Primer pairs used for RT-PCR (antioxidant enzymes genes) and Real Time PCR (retinoid receptors genes).

\begin{tabular}{ccccc}
\hline Gene name & GenBank Accession No & Forward primer 5'-3' & Reverse primer 5'-3' & Fragment size \\
\hline CAT & NM_012520 & CGACCGAGGGATTCCAGATG & ATCCGGGTCTTCCTGTGCAA & 174 bp \\
GPx1 & NM_030826 & CGGTTTCCCGTGCAATCAGTT & ACACCGGGGACCAAATGATG & 225 bp \\
SOD & NM_017051 & AGCTGCACCACAGCAAGCAC & TCCACCACCCTTAGGGCTCA & $200 \mathrm{bp}$ \\
RAR $\alpha$ & NM_031528 & CGCCTGTGAGGGCTGTAAG & ATGCCCACTTCGAAGCATTT & $150 \mathrm{bp}$ \\
RXR $\beta$ & NM_206849 & CGAAGCTCAGGCAAGCACTA & TCCTGTACCGCCTCCCTTTT & $200 \mathrm{bp}$ \\
\hline
\end{tabular}

